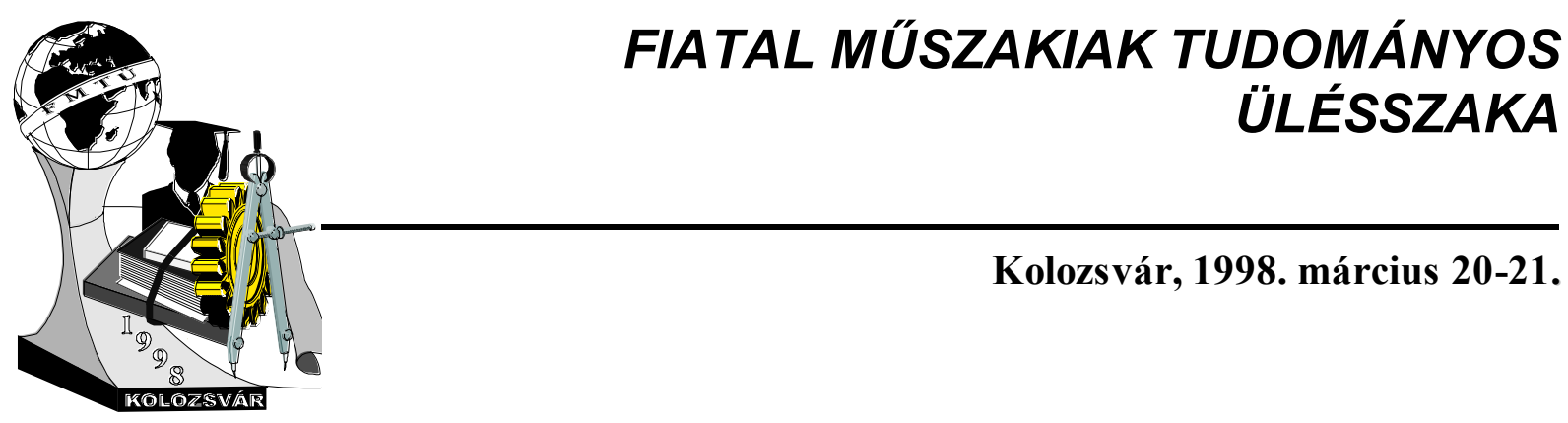

\title{
Porózus Gradiens Anyagok Vizsgálata
}

\author{
Bacsán Norbert, Bárczy Pál, Csontos Attila, Jónás Zsolt
}

\section{Investigation on Porous Gradient Materials}

The properties of the gradient materials are described by the monotone changes of the characteristic physical parameter in the function of the distance and by the strongly direction dependence. Demanding on the development of the Universal Multizone Crystallisator (UMC) a new investigation was started on the field of the controlled heat conductivity insulation materials. The UMC could be controlled better if the heat conductivity is higher in radial than axial direction. The value and the direction of the heat conductivity is mainly depends on the shape and the quantity of the pores or the holes. For better understanding the gradient materials it is necessary to investigate the relationship between the structure of the porous materials and the heat conductivity.

\section{A hővezetési tényező anyagszerkezet függése}

A felhasználás szempontjából ideális hővezetési paraméterekkel rendelkező anyag tervezésénél három anyagi méretskálát kell figyelembe venni.

Az atomi szinten a hővezetést a kristályszerkezet és az anyag elektronszerkezete szabja meg. Így például a fémes anyagoknál az elektronok, a szigetelő anyagoknál a fononok játsszák a döntő szerepet. Mielött a fémes anyagokat jó hővezetőnek a kerámiákat rossz hővezetőnek könyvelnénk el megemlítendő, hogy a kerámiák avagy fononvezetők közül kerül ki a legjobb hővezetô a gyémánt (2000 $\mathrm{W} / \mathrm{mK}$ amíg a rézé $403 \mathrm{~W} / \mathrm{mK}$ ).

A hővezetés irányfüggősége atomi szinten is megvan a pirolitikus bórnitrid esetében a különbség a párhuzamos és a merőleges irányok között két nagyságrend. A különböző kristálytani irányokban más és más. A fémek hővezetésénél mind a fononvezetés mind az elektronvezetés szerepet játszik, általában az elektronvezetés a domináns. A fononvezetőknél és az elektronvezetőknél a szennyezö- vagy ötvözőtartalommal egyaránt változtatható a hővezetés. Szilárd oldat esetében a függvény konvex vagyis az ötvözö növekedésével csökken és minimuma van. Az amorf tartalom növekedésével azonban monoton csökkenő függvény. A kristályos anyagokhoz képest a hővezető képesség akár egy nagyságrenddel is csökkenhet.

$\mathrm{Al}_{2} \mathrm{O}_{3}$ hővezetési tényezője viszonylag nagy, magas hőmérsékletü szigetelőnek mégis használnak szálas $\mathrm{Al}_{2} \mathrm{O}_{3}$-ot. A 3 nagyságrend eltérést a mikroszerkezet adja [1]. Az anyagban lévő pórusok, szálak, zárványok és a szemcseszerkezet erősen megváltoztatják nemcsak a hővezetés nagyságát, hanem a hővezetés irányára is befolyással bírnak. Például szálas kompozit anyagnál, ha a szál jó hővezető, a szál irányában több hő távozik el mint arra merőlegesen. Ugyanez tapasztalható textúrás szerkezet esetében is. Hosszúkásan elnyújtott szemcsék esetében a hővezetés a szemcsére merőleges irányban akár a fele is lehet a szemcsével párhuzamos irányban mért értéknek. A több fázisú anyagok hővezetése sorosan és 
párhuzamosan kapcsolt vezetők (nem ellenállások) analógiáját felhasználva vezethető le. Párhuzamosan kapcsolt vezetőknél a hővezetést egyszerüen összeadódik. Sorosan kapcsolt vezetőknél az eredő vezetés reciproka lesz egyenlő a komponensek hővezetésének a reciprokösszegével.

A szemmel látható tartományban, a makroszinten a gradiens szerkezetet lényegében egymásra helyezett rétegekkel lehet elérni. Axiális irányban a probléma a kemencetéren belül, a kemencetérben és a kemencefalazatban egyaránt megfogalmazható és ha nem is folyamatosan, de kis lépcsők alkalmazásával technikailag megoldható. Európaszerte mégis megindult a kísérletezgetés abban az irányban, hogy egyetlen anyagon belüli tulajdonságváltoztatással az építés és szerelés teljesítóképességét fokozni lehessen. Az anyagtudomány magát az anyagot kívánja céljainknak megfelelővé tenni.

\section{A modellanyag}

A modellanyag kiválasztásánál elsődleges szempont volt az anyag formálhatósága és szeletelhetősége. Az előbbi a hővezetési tényező meghatározásához szükséges próbatestek kialakításánál az utóbbi a mikroszkópiai vizsgálatoknál volt fontos. A műanyaghabok megfelelnek ezeknek a kritériumoknak ráadásul a pórusszerkezetük és a hővezetési tényezőjük típusonként és fajtánként különböző. A kiválasztott extra nagy porozitású lemezekből gradiens anyag építhető.

\section{A modellanyag szerkezete}

A müanyag habok szemmel látható szemcsékből un. habosított polimer gyöngyökből állnak. Ez alkotja a hab makroszerkezetét . A gyöngyök finom összepréselésével állítják elő magát a müanyag hab lemezeket. A préselés azonban sohasem lehet tökéletes ezért a gyöngyök között nyílt makropórusok maradnak (1.a. ábra). A hab mikroszerkezete (1.b. ábra) poliéderekböl (pentagonális dodekahedron) áll amelyeket vékony hártyák (vastagságuk $\mathrm{kb} .1 \mu \mathrm{m}$ ) választják el egymástól.

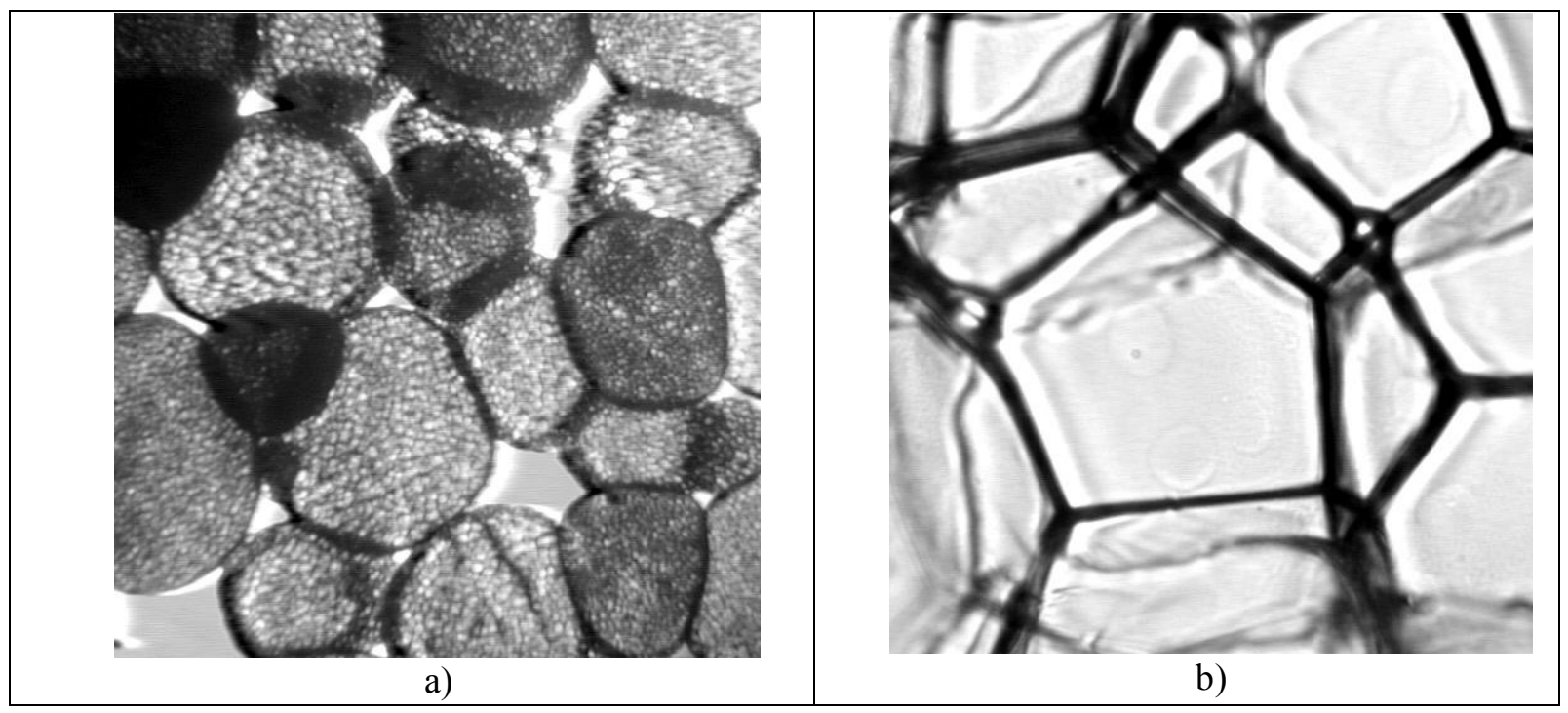

1.ábra. A modellanyag (a) makropórusainak (képszélesség 7,5 mm) és (b) mikropórusainak (képszélesség 0,6 $\mathrm{mm}$ ) fényképe

Több hártya érintkezésénél az úgynevezett csomóvonalaknál a réteg megvastagszik (2.ábra). Vékony rétegeknél nem számolhatunk a tömb anyag hővezetési tényezőjével [2] itt a hővezetési tényező már arányos lesz a rétegvastagsággal ezért valószínüsíthető, hogy a hő nagyrészt a csomóvonalak mentén áramlik. 


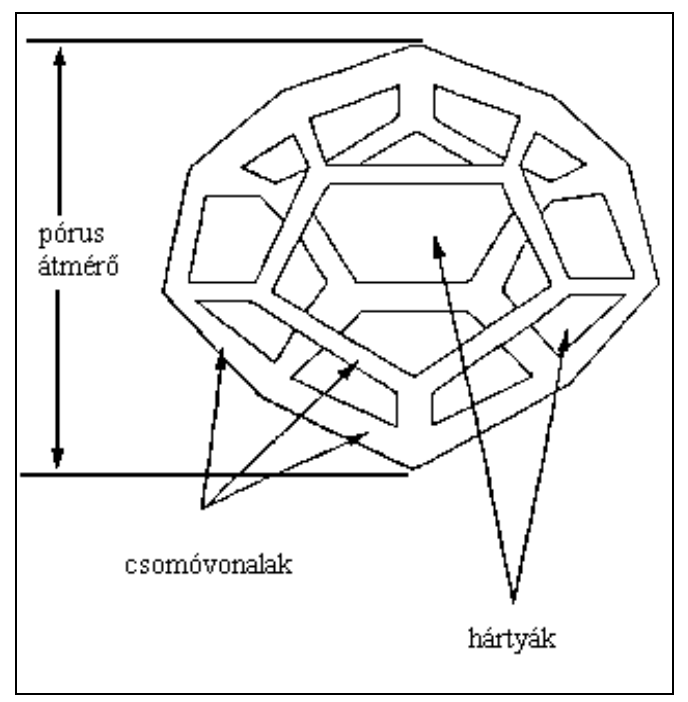

2.ábra. A mikropórus szerkezete

Anizotróp póruseloszlás és orientáció a hővezetési tényező orientálódását vonja maga után. Egy heterogén anyag, a mi esetünkben pórus-mátrix, esetében az egész test effektív hővezetésében a mátrix hővezetési tényezőjének van döntő szerepe.

1.táblázat. A vizsgált müanyaghabok hővezetésének és porozitásának értékei (külső forrásból). A müanyag valódi sürúsége $\rho_{\mathrm{t}}=1040$ $1090 \mathrm{~kg} / \mathrm{m}^{3}$.

\begin{tabular}{|c|c|c|}
\hline $\begin{array}{l}\text { Hóvezet' } \\
\text { képesség } \\
\lambda, \mathrm{W} / \mathrm{mK}\end{array}$ & $\begin{array}{l}\text { Sürüség } \\
\rho, \mathrm{kg} / \mathrm{m}^{3}\end{array}$ & $\begin{array}{r}\text { Porozitás } \\
\Pi,\left(\rho_{\mathrm{t}}-\rho\right) / \rho\end{array}$ \\
\hline 0.0411 & 10 & 0.990826 \\
\hline 0.0369 & $\begin{array}{lr}15 \quad \text { kisebb } & \text { p } \\
\text { diffúziós } & \text { tén } \\
\text { kevesebb } & \text { nyit } \\
\text { pórus } & \end{array}$ & 0.986239 \\
\hline 0.0339 & 20 & 0.981651 \\
\hline 0.0329 & 25 & 0.977064 \\
\hline 0.0331 & 30 & 0.972477 \\
\hline 0.0366 & $\begin{array}{l}15 \text { nagyobb p } \\
\text { diffúziós tén } \\
\text { több nyitott pórus }\end{array}$ & 0.986239 \\
\hline
\end{tabular}

\section{A porozitás és a hővezetési tényező kapcsolata}

Egy összetett anyag úgynevezett effektív hővezetési tényezője ( $\left.\lambda_{\text {eff }}\right)$ vezetési, sugárzási és konvekciós tagból tevődik össze. Számszerü értékét a külső, környezet hőmérséklete és nyomása, és belső, anyagszerkezettel összefüggő paraméterek (porozitás mértéke; pórus illetve szemcse alak és méret; makro és mikro repedések geometriája) határozzák meg. Az effektív hővezetési tényező a döntően sủrünek tekintett mátrix hővezetési tényezőjének, a pórusok emissziós tényezőjének, és természetesen ezen utóbbiak méretének, alakjának és eloszlásának függvénye.

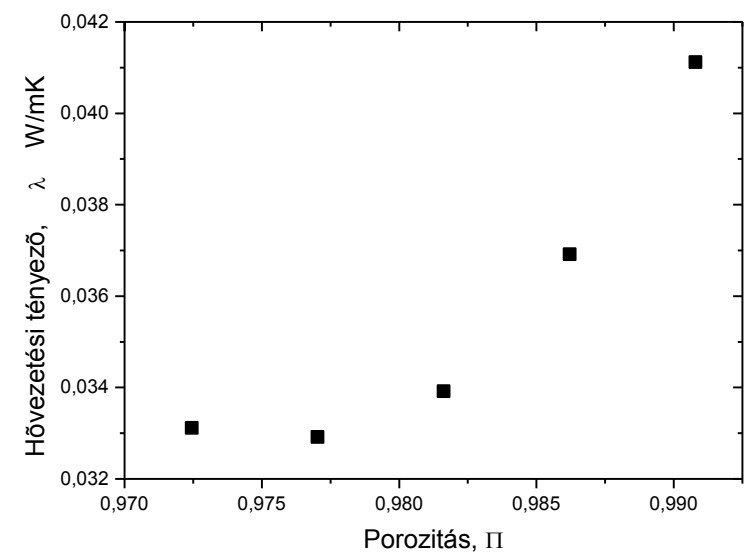

3.ábra. A hővezetési tényező porozitás függése

$\mathrm{Az}$ 1.táblázat és a 3.ábra a porozitás függvényében ábrázolja különböző műanyaghabok hővezetését. A hővezetési tényezőt tranziens módszerrel 4 különböző makro- és mikroporozitású mủanyaghabon mértük meg. A mért értékeket a 2.táblázat tartalmazza

2.táblázat. A müanyaghabok mért értékei

\begin{tabular}{|l|l|l|l|l|l|}
\hline Mintajj & $\begin{array}{l}\text { Mért } \\
\text { sürüség } \\
{\left[\mathrm{kg} / \mathrm{m}^{3}\right]}\end{array}$ & $\begin{array}{l}\text { Makro-pórusok mennyisé } \\
\text { képelemzö-vel tf\% }\end{array}$ & $\begin{array}{l}\text { Mért hödiffúz } \\
\text { tényezö }\left[\mathrm{m}^{2} / \mathrm{s}\right]\end{array}$ & $\begin{array}{l}\text { Mért hővezetési tényez } \\
{[\mathrm{W} / \mathrm{mK}]}\end{array}$ & $\begin{array}{l}\text { Páradiffúziós tényező } \\
{[\mathrm{g} / \mathrm{msMPa}]}\end{array}$ \\
\hline 1 & $11,9 \pm 0,3$ & 3,56 & $5.6 \cdot 10^{-6}$ & 0.0563 & 0,0052 \\
\hline 2 & $13,5 \pm 0,4$ & 4,79 zárt pórusok is & $2.7 \cdot 10^{-6}$ & 0.0407 & 0,0050 \\
\hline $\mathrm{Ap}$ & 25 & 7,03 & $1.5 \cdot 10^{-6}$ & 0.0377 & \\
\hline $\mathrm{Na}$ & 14 & 2,42 & $2.7 \cdot 10^{-6}$ & 0.0380 & \\
\hline
\end{tabular}


A 4. ábra az elkészült gradiens anyagban található rétegek hővezetési tényezőjét tartalmazza.

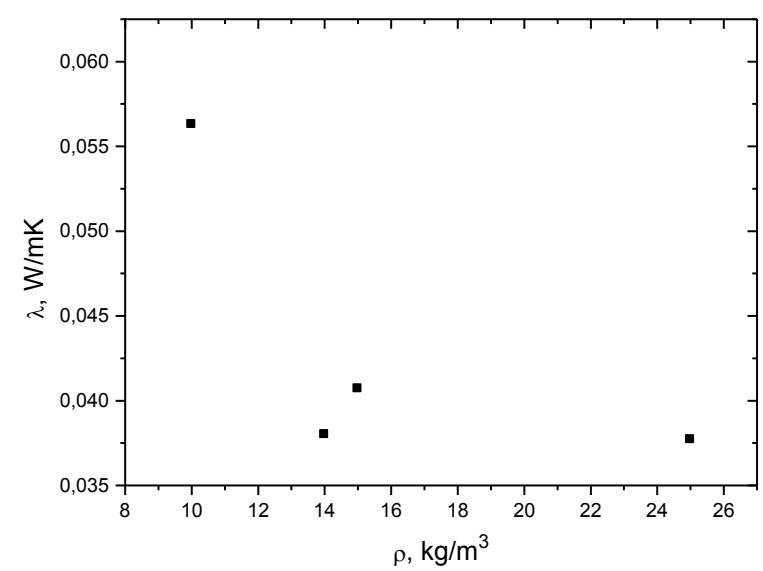

4.ábra. Az általunk mért hővezetési tényező és látszólagos sürüség kapcsolata

\section{Értékelés}

A téma, pórusos szerkezetủ anyagok irányfüggő hővezetésének vizsgálata, napjainkban reneszánszát éli, amit az irodalom jegyzék bizonyít. Az anyagok hővezetési tényezőjének porozitásuk, pórusszerkezetük függvényében adódó első, alapvető matematikai összefüggéseit már századunk 30-as 40-es éveiben felismerték. Ezek pontosítására, kiegészítésére azonban csak a modern szerkezetvizsgálat, a számítógépes kiértékelö rendszerü képelemzésnek alávetett SEM (Scanning Electron Microscopy) felvételek, alapján vált, válik napjainkban lehetővé. Ezen munka fö célja a bevezetöben említett USK fejlesztés keretein belül csatlakozás ehhez a nemzetközi kutatási irányvonalhoz. Véleményünk szerint ennek első, sikeres lépését tettük meg a fentebb vázolt vizsgálatokkal, mikor is megmértük a homogén póruseloszlású minták porozitás függő hővezetését. Az adatokat felhasználva egyszerü gradiens anyagot kaptunk mikor egy szendvicsszerkezetet állítottunk össze a fenti anyagokból úgy, hogy a kemence tengelyétől távolodva az egyre kisebb hővezetési tényezőjü anyagrétegeket fektetjük egymásra a kemence falával párhuzamosan. Ez a szerkezet egyre erősebb gátat vet a hőáramnak a kemencétől távolodva, miközben az egyes rétegeken belül a hő terjedése könnyebben megy végbe. Ez a megoldás, a határfelületi jelenségektől eltekintve, egyenértékü egy olyan pórusos anyag használatával, melynek porozitása a vizsgált irányban változik.

\section{Irodalomjegyzék}

1. A.L.Loeb, A Theory of Thermal Conductivity of Porous Materials. J. Am. Ceram. Soc. Vol. 37, no.2. 1954

2. Gliksman, L.R., Stewart, J., Insulation Materials:Testing and Application: Third Volume, ASTM STP 1320, p. 307-334.

Babcsán Norbert / egyetemi tanársegéd

Nemfémes Anyagok Tanszéke / Miskolc-Egyetemváros 3515 Hungary

T./F.:36-46-365-924, e-mail: femnorbi@gold.uni-miskolc.hu 